\title{
The influence of brand and events on the formation of tourist destination image: A contribution to the explanation of loyalty
}

\author{
José Antonio Folgado Fernández ${ }^{1}$
}

Received: 10/01/2015

\begin{abstract}
${ }^{1}$ Centro Universitario de Plasencia, Avda. Virgen del Puerto, nº 2 10600, Plasencia, Cáceres, Spain; tel: +34 927257000; e-mail: jafolgado@unex.es
\end{abstract}

Supervisors: Dr. José Manuel Hernández-Mogollón and Dr. Paulo Oliveira Duarte

Institution awarding the Ph. D. Degree: University of Extremadura, Spain.

Date of defence: 04/04/2014

(C) 2015 Varna University of Management. All rights reserved

Citation: Folgado, J. (2015) The influence of brand and events on the formation of tourist destination image: A contribution to the explanation of loyalty. Doctoral Dissertation Summary. European Journal of Tourism Research 11, pp. 158-161

\section{Goal and objectives of the dissertation Goal}

The main goal of this research was to improve the understanding of the degree of influence that events, infrastructure and brand have on destination image and tourist loyalty.

\section{Objectives}

This overall goal can be broken down into seven more specific objectives, namely:

Objective one: To develop an overall conceptualisation of tourist destination image. Objective two: To measure the influence that different types of events have on destination image and loyalty.

Objective three: To understand fully the theoretical framework on which our study is based, providing an exhaustive analysis of destination image and its implications.

Objective four: To analyse different explanatory theories of the influence of events 158 on the development of tourist destination images, as well as the influence of different forms of communication and event and regional brands.

Objective five: To propose an integrative model of destination image and relate this with the different variables that form destination images - paying particular attention to the effect of events, infrastructure and brand - as these relate to individual tourists' loyalty.

Objective six: To contribute to a better understanding of the formation of tourism destination images, determining indicators, measurement scales and the degree of each variable's influence on lasting images and tourist loyalty - within this study's proposed model.

Objective seven: To understand the importance of destination image through an analysis of results obtained for particular types of rural destinations with extensive 
cultural and natural heritage, in which unique events are celebrated.

\section{Methodology}

The first part of this thesis is a review of the literature on destination image and the celebration of events. Based on this review, a model was formulated, which could be tested empirically, using the findings of current researches on these topics.

The second section is devoted to the empirical study. The fieldwork was done in the Extremadura region of Spain, an area of high cultural and natural value, with four distinct zones of great interest to tourists. These centre on the cities of Cáceres, Mérida, Trujillo and Plasencia (Valle del Jerte). This study paid special attention to locations in which events - selected for their wide impact and strong regional flavour - are celebrated. The total sample was divided into two groups based on typology, one being cultural events (the Holy Week in Cáceres and the Classic Theatre Festival in Mérida) and the other, gastronomy events that revolve around quite traditional, local products (the Trujillo Cheese Fair and the Cherry Blossom Festival in the Jerte Valley). The sample population was tourists over 18 years old who attended the four events studied.

The partial least squares (PLS) regression technique was used to test the hypotheses of the research model (Hair, Ringle and Sarstedt, 2011). A questionnaire was designed and validated as the measurement instrument. This questionnaire was administered during the events, from March to July 2013 , to a non-probability convenience sample of 1,227 tourists (611 for the cultural sample and 616 for the gastronomy sample).

Conclusions, limitations and future lines of research make up the last section of the thesis. Table 1, in which the sample's characteristics are presented, gives the technical details of the survey.

\section{Results}

In general, the properties of the measurement models are acceptable in terms of both reliability (internal consistency) and validity (convergent and discriminant validity). The results obtained show that the events have a positive influence on destination images for the sample studied. While the permanent infrastructure of these destinations has a positive influence on destination images for the cultural model, this result was not produced for the gastronomy model. For its part, intentional communication has a nonsignificant effect on the event brand for both sample groups. These results provide support for both the theoretical basis and practical analysis of destination image, since the model dynamics could prove relevant for the four cities and their events.

\section{Theoretical conclusions}

One of the key theoretical contributions of this research is its findings on the influence of overall destination image on the process of generating tourist loyalty for both cultural and

Table 1. Technical data of the research

\begin{tabular}{|c|c|}
\hline Characteristics & Survey \\
\hline Universe & Tourists over 18 years old \\
\hline Data collection methods & Personal interviews \\
\hline Types of questions & Questions with responses on a Likert scale \\
\hline $\begin{array}{l}\text { Dates when the information was } \\
\text { gathered }\end{array}$ & March to July, 2013 \\
\hline Geographic scope & $\begin{array}{l}\text { Cáceres, Mérida, Trujillo and Plasencia (Valle del Jerte) in the } \\
\text { Extremadura region, Spain }\end{array}$ \\
\hline Size of sample obtained & 1,227 valid questionnaires \\
\hline Statistical tests applied & $\begin{array}{l}\text { Descriptive analysis, correlations, regressions and structural } \\
\text { equations }\end{array}$ \\
\hline Statistical programmes used & SPSS version 15.0 and Smart PLS 2.0 \\
\hline
\end{tabular}


The influence of brand and events on the formation of tourist destination image: A contribution to the explanation of loyalty. Doctoral Dissertation Summary.

gastronomy events (Campon, Hernández and Alves, 2012). Another important contribution can be that the infrastructure, events and brand show different levels of influence on overall destination image and tourist loyalty, depending on the type of event (Getz, 1997). Infrastructure significantly influences destination image for the cultural sample, but not for the gastronomy sample. Intentional communication, on the other hand, has no influence on the event brand for any of the samples analysed, while unintentional communication is significant for the cultural model. Only the event brand has a positive effect on destination images for the gastronomy model.

Therefore, the overall process of developing a destination image can be different depending on the type of event studied (Boo and Busser, 2005). Besides cognitive and affective aspects (adequately confirmed in the literature), events and regional brand are the most important active elements in the formation of tourist destination image (San Martín and Rodríguez del Bosque, 2008).

\section{Practical application of the dissertation}

Both samples produced similar values for tourists visiting locations again and those who had come to the destination for the first time. However, the majority of those interviewed had never attended the events before. These data suggest that destination managers need to implement initiatives that encourage repeated visits, based on marketing aimed at their target public.

Both sample groups showed a shift in tendencies for intentional communication strategies to place more importance on the Internet over traditional media. This trend has made it easier to spread marketing messages more effectively within this new context (Folgado, Di Clemente, Hernández Mogollón and Campón, 2013).

For destinations to be more competitive, they should ensure that they contain a number of infrastructure or permanent elements that support tourist activities, giving the administrators involved strategic functions in conserving, managing and communicating the destinations' image. Regarding event brands, the findings verify that this has no decisive influence on destination images for either sample group, making it possibly of interest to develop a single destination brand image integrated with the specific brand of the events.

Last, in reference to tourist loyalty, the most important values in both sample groups were found for loyalty to the destination resulting from the events. This indicates that destination managers could find it useful to develop renovation and improvement projects.

\section{Content of the dissertation}

\section{Abstract of chapter one}

The first chapter gives a general presentation of the research problem, showing its relevance in both academic and tourism management contexts. The study's general purpose and its specific objectives are detailed, as well as the structure of the research and the plan implemented to achieve the desired outcomes.

\section{Abstract of chapter two}

The second chapter offers an extensive review of the literature on destination image and the most important models used in image formation. In addition, the contribution of image to destination loyalty is examined, along with the nature of tourist loyalty.

\section{Abstract of chapter three}

In the third chapter, the conceptual framework and the planning of events are described through a review of the literature on the nature, classification and key variables of events. The examination of these dimensions provides a better understanding of the process that enhances destination images through unique events that contribute to the development of sustainable tourism throughout the year, diminishing the effect of seasonality.

\section{Abstract of chapter four}

The fourth chapter analyses brands as the element connecting all the communication 
initiatives implemented. Brand management is examined as a whole, as well as its effects within the tourism sector, analysing in detail the main types of brands present in the sector. In addition, the most important models described in the literature - which include how brand and destination image interrelate are evaluated.

\section{Abstract of chapter five}

Based on the review of literature on destination image, this chapter details the research problem, identifying the measurement variables, hypotheses, relationships and possible response paths. Last, the proposed model is described, which includes the effects of brand and events on destination image and loyalty (BEDIL model).

\section{Abstract of chapter six}

Chapter six covers questions related to the empirical study, including its plan and procedures. The themes related to the research focus and method follow, including the research setting, data collection instruments, sample selection, fieldwork execution and statistical techniques used to process and then analyse the information obtained.

\section{Abstract of chapter seven}

This chapter describes how the data collected were analysed, and then presents and discusses the results. A descriptive analysis is first done on the sociodemographic characteristics of the respondents, profiles of their behaviour and measurement scales. This evaluation is followed by the analysis of the research model (i.e. measurement and structural models) based on the samples studied: cultural and gastronomy events.

\section{Abstract of chapter eight}

This chapter outlines the main theoretical and practical conclusions obtained from the study.

\section{References}

Boo, S., J. Busser (2005) Impact analysis of a tourism festival on tourist destination images. Event Management 9 (4), 223-237

Folgado, J., Di Clemente, E., Hernández Mogollón, J., Campón, A. (2013) Influencia de la imagen del destino en el comportamiento del turista cultural. Un estudio empírico en la ciudad de Plasencia como destino de turismo cultural. Revista de Estudios Económicos y Empresariales 25, 91114

Getz, D. (1997) Event management \& event tourism. New York: Cognizant Communication Corp.

Hair, J., C. Ringle, M. Sarstedt (2011) PLSSEM: Indeed a Silver Bullet. The Journal of Marketing Theory and Practice 19 (2), 139-152

San Martín, H., I. Rodríguez del Bosque (2008) Exploring the cognitiveaffective nature of destination image and the role of psychological factors in its formation. Tourism Management 29 (2), 263-277 